\title{
Aksi Bersih Pantai (Coastal Cleanup) Di Pantai Labuhan Haji, Kabupaten Lombok Timur Guna Mendukung Kesadaran Wisatawan Tentang Kebersihan Pantai
}

\author{
${ }^{1}$ Handri Jurya Parmi \& ${ }^{2}$ Muslihuddin Ani \\ ${ }^{1}$ Prodi Pemanfaatan Sumbedaya Perairan, Fakultas Perikanan, Universitas Gunung Rinjani \\ Jalan Raya Mataram - Lab. Lombok KM. 50, Selong Lotim Telp. (0370) 631620 \\ ${ }^{2}$ Lembaga Penelitian Coastal Enviromental \& Fisheries \\ Perumahan Griya Pesona Madani Block F02 Kel. Denggen Kec. Selong Lotim - NTB
}

\begin{abstract}
Abstrak. Pantai Labuhan Haji merupakan daerah wisata bahari untuk kalangan wisatawan domestik yang terdapat di Kabupaten Lombok Timur, Nusa Tenggara Barat. Akhir-akhir ini pantai tersebut menjadi buah bibir dikalangan para wisatawan karena terdapat tumpukan sampah di bibir pantai tersebut. Hal ini menjadi masalah utama bagi perkembangan pariwisata di Pantai Labuhan Haji. Kegiatan bersih pantai berupa konsep International Coastal Cleanup (ICC) dilakukan dan sekaligus diperkenalkan langsung di lokasi tersebut. Ada beberapa hal yang dicapai dalam kegiatan tersebut. Pertama, warga dan para wisatawan akhirnya paham terhadap pentingnya menjaga kebersihan pantai. Kedua, kegiatan tersebut dapat meningkatkan pengetahuan dan kepedulian warga terhadap beberapa jenis pencemar dan sumber pencemar di sekitar pantai. Ketiga, perlunya keberlanjutan program serta penambahan fasilitas kebersihan di lokasi Pantai Labuhan Haji.
\end{abstract}

Kata Kunci: Pantai Labuhan Haji, Coastal Cleanup, Sampah

\section{PENDAHULUAN}

Wilayah pesisir merupakan daerah pertemuan antara darat dan laut yang memiliki sumberdaya potensial di Indonesia. Sumberdaya ini sangat besar yang didukung oleh adanya garis pantai sepanjang sekitar $81.000 \mathrm{~km}$ (Dahuri, et.al., 2002). Dengan panjang garis pantai tersebut, wisata bahari merupakan potensi yang sangat besar yang dimiliki Indonesia.

Pulau Lombok memiliki daerah wisata pantai yang sangat terkenal, hampir seluruh kabupaten dan kota yang berada di Pulau Lombok memiliki wisata pantai. Pantai Labuhan Haji merupakan salah satu pantai yang sangat terkenal di Kabupaten Lombok Timur. Lokasi pantai ini berada sekitar $7 \mathrm{~km}$ kearah timur dari pusat Kota Selong.

Pantai ini tidak ramai setiap hari, pantai ini ramai dikunjungi ketika hari libur sekolah dan hari besar lainnya. Pantai tersebut menawarkan panorama sunrise yang memanjakan para wisatawan. Banyaknya jumlah wisatawan tersebut tentu saja akan membawa dampak, berupa pencemaran wilayah pesisir dan laut Labuhan Haji. Akhir- akhir ini pantai tersebut menjadi buah bibir dikarenakan sampah yang menumpuk di bibir pantai yang dapat mengurangi estetika pantai tersebut. Sejauh pengetahuan penulis, tidak banyak informasi serta kajian tentang tingkat pencemaran pantai di lokasi ini.

Salah satu upaya yang diharapkan daapat mendukung kebersihan pesisir adalah upaya pro-aktif dari semua kalangan, baik dari pemerintah, masyarkat setempat, wisatawan dan pemangku kepentingan. Menurut Handaka et. al., 2007, menyarankan agar dilakukan upaya kerja bakti secara rutin utuk membersikan pantai ssebagai salah satu langkah yang dapat diambil untuk menjaga kelestarian lingkungan pesisir.

Hal ini selaras dengan berbagai aktifitas atau aksi yang dilakukan oleh masyarakat internasional dalam menjaga lingkungan pesisir ini. Salah satu lembaga internasional yaitu Ocean Concervacy secara rutin melakukan kampanye bersih pantai (coastal cleanup). Lembaga ini melakukan standarisasi terhadap pencemar yang ditemukan di pesisir, danau dan laut serta melakukan analisis terhadap hasil tersebut. 
Tujuan kegiatan ini dapat memberikan contoh dan pengertian mengenai metode kegiatan bersih pantai dengan menggunakan standar internasional. Sehingga diharapkan dapat meningkatkan kesadaran akan kebersihan pantai bagi masyarakat setempat.

\section{TINJAUAN PUSTAKA}

Pesisir dan lautan sangat penting bagi kehidupan manusia. Menurut Small dan Nicholas (2003), populasi manusia yang beraktivitas tetap di wiayah $100 \mathrm{~km}$ dari pantai adalah $33 \%$ dari populasi manusia di dunia (1.2 miliar jiwa pada tahun 2002) dan meningkat terus sampai 50\% pada tahun 2030 (Adger et. al., 2005). Pesisir dan laut menopang hampir setengah kebutuhan dasar manusia (Field et. $\boldsymbol{a l}$. , 1998), seperti beberapa pangan dari perikanan (Pauly dan Christensen, 1995).

Populasi manusia di pesisir sangat mempengaruhi peningkatan sampah laut. Indonesia menjadi pembuang sampah laut plastik kedua terbesar di duia setelah China, berdasarkan studi tahun 2010 yang dilakukan pada 192 negara pesisir oleh Jambeck $\boldsymbol{e t}$. al., (2015). Indonesia dengan populasi penduduk di pesisir 187.2 juta jiwa dan kebiasaan masyarakat membuang sampah laut plastik $0.52 \mathrm{~kg} /$ orang/hari menjadikan Indonesia penyumbang sampah laut plastik sebesar 3.32 juta metrik ton/tahun (Jambeck et al. 2015). Penelitian tersebut hanya menghitung sampah laut plastik saja, sedangkan sampah laut terdiri dari berbagai macam material padat baik organik maupun anorganik (Smith dan Marlic 2013). Jenis pencemar inilah yang menjadi permasalahan utama di beberapa lokasi wisata di Indonesia. Berbagai usaha menjaga kebersihan di daerah pesisir pantai tersebut akan sangat penting.

Kegiatan bersih pantai (Coastal Cleanup) ini merupakan bagian dari upaya warga dunia untuk perduli terhadap kebersihan lingkungan pesisir. Kegiatan ini bersifat internasional dan melibatkan para relawan untuk melakukan kegiatan bersih pantai dengan metode survey, biasanya dilakukan dalam periode yang bersamaan. Sehingga dikenal pula dengan International Coastal
Cleanup (ICC) yang dilakukan secara serentak di berbagai pesisir pantai di seluruh dunia. Kegiatan ini juga memberikan kesempatan bagi masyarakat, wisatawan serta relawan dari Indonesia untuk dapat berpartisipasi dalam kampanye kebersihan pesisir pantai ini. ICC merupakan konsep kegiatan yang efektif untuk meningkatkan kesadaran masyarakat terhadap pencemaran pesisir pantai melalui pengalaman langsung survey dan mengambil sampah secara langsung (Ohkura dan Kojima, 2007). Berdasarkan Ohkura dan Kojima (2007), kegiatan tersebut dapat memberikan tantangan dan pengetahuan para peserta akan beberapa hal berikut :

1. Sumber pencemaran pesisir pantai berasal dari sampah yang dihasilkan dari kehidupan masyarakat sehari-hari yang dibuang melalui sungai atau saluran lainnya.

2. Setiap orang menghasilkan sampah yang mudah terlihat dan sudah dianggap maklum.

3. Solusi yang terbaik adalah mengembangkan komunitas masyarakat yang peduli dan handal untuk mencegah pencemaran tersebut serta mengembangkan masyarakat untuk memiliki orientasi daur ulang.

\section{MATERI DAN METODE Kerangka Pemecahan Masalah}

Desa Labuhan Haji memiliki masalah yang serius dengan sampah di sekitar pesisir pantainya. Hal ini disebabkan oleh meningkatnya aktivitas pariwisata di pantai tersebut serta banyaknya warga yang membuang sampah ke aliran sungai sehingga bermuara di Pantai Labuhan Haji. Solusi alternatif di Desa Labuhan Haji akan menjadi fokus utama penulis. Salah satu solusi alternatif yang dapat dilakukan adalah dengan kegiatan bersih pantai yang dapat melibatkan banyak elemen. Kegiatan ini juga berpotensi untuk meingkatkan kesadaran warga tentang menjaga kebersihan lingkungan, khususnya Pantai Labuhan Haji. Pemasangan tong sampah serta spanduk tentang bahayanya sampah akan membantu mengurangi volume sampah di pesisir pantai tersebut. Selain itu, sosialisasi terhadap warga yang tinggal 
dipinngiran sungai agar tidak membuang sampah ke sungai perlu juga ditingkatkan.

\section{Metode yang digunakan (Tahapan Kegiatan)}

Metode yang digunakan dalam pelaksanaan kegiatan ini adalah mengikuti standar International Union Concervancy of Nature (IUCN) dengan disediakan tabel data standar yang berisi bahan-bahan pencemar yang didapatkan di lokasi kegiatan. Data pencemar yang dieroleh kemudian akan dianalisa bersama-sama lembaga IUCN. Adapun tipe bersih pantai yang akan diakukan adalah berupa shore cleanup (Ocean Concervancy, 2011) yang meliputi daerah pasang tertinggi hingga mendekati daerah bukit pasir yang tidak terkena pengaruh pasang surut air laut.

Peserta terdiri dari wisatawan, komunitas pemuda pencinta lingkungan, warga sekitar yang bersedia menjadi sukarelawan. Peserta bersih pantai diberikan penejelasan diawal mengenai teknis pelaksanaan bersih pantai agar metode yang digunakan tidak salah dan mempermudah dalam menganalisis data. Termasuk menginformasikan bahan-bahan pencemar yang kan dibersihkan dan dilakukan pendataan. Peserta akan melakukan pre-test sebelum kegiatan dan akan diberikan juga lembaran kuisioner yang akan diisi sebelum melakukan kegiatan bersih pantai.

Para peserta akan dibagi menjadi beberapa kelompok kecil sebanyak 5 orang dan dibagi menjadi beberapa titik wilayah bersih pantai. Setiap tiga kelompok kecil akan melakukan penyapuan wilayah sejauh $50 \mathrm{~m}$. Masing-masing kelompok akan disertai 5 buah kantong sampah plastik besar (trash bag), kartu bersih pantai standar, polpen, serta sarung tangan. Setiap kelompok mencatat bahan-bahan pencemar seperti yang terdapat dalam kartu standar. Apabila telah selesai kegiatan, setiap kelompok mengumpulkan kantong plastik yang berisi bahan pencemar di titik yang teah ditentukan. Kantong plastik tersebut akan ditimbang dan kartu standar dikumpulkan ke penulis. Kemudian kuesioner pasca kegiatan diberikan kepada para peserta untuk mengetahui umpan balik kegiatan tersebut.

\section{HASIL DAN PEMBAHASAN Pra Kegiatan}

Sebelum peserta melakukan kegiatan bersih pantai, penulis melakukan pelatihan berupa penjelasan umum serta teknis metode International Coastal Cleanup (ICC) yang dilakukan di Kantor Komunitas Plastik Bergerak pada tanggal 2 Februari 2019. Terdapat 30 orang peserta yang hadir dalam penjelasan tersebut yang terdiri dari anggota komunitas Plastik Bergerak, Mahasiswa Perikanan UGR, anggota green generation Lombok Timur, dan para sukarelawan dari wilayah sekitar pantai. Para peserta juga mendapatkan brosur singkat yang berisi tentang konsep ICC serta teknis pelaksanaannya.

Berdasarkan hasil wawancara dan kuesioner yang diberikan kepada para peserta sebelum kegiatan, diperoleh data bahwa sekitar $60 \%$ peserta belum mengetahui cara melakukan bersih pantai, sedangkan $40 \%$ telah mengetahui cara membersihkan pantai. Dari data $40 \%$ yang mengetahui cara membersihkan pantai, ternyata masih belum sepenuhnya mengetahui cara yang benar. Mereka beranggapan bahwa bersih pantai itu hanya sebatas membersihkan pantai dan membakar sampah ditepi pantai ataupun membuang sampah langsung ke TPA. Para pedagang disekitar pantai senantiasa membersihkan pantai yang masih menjadi wilayah sekitar warungnya. Sedangkan sampah yang berasal dari muara sungai dibersihkan oleh para komunitas pencinta lingkungan tapi hal itu masih belum efektif karena belum ada dukungan dari pemerintah. Selain itu, tidak adanya tong sampah di daerah wisata ini sangat disesalkan oleh para peserta. Solusi yang diberikan oleh para peserta untuk kebersihan pantai tersebut adalah $50 \%$ peserta menyatakan bahwa di lokasi pantai tersebut harus diberikan tong sampah, 30\% menyarakan untuk dilakukan kegiatan bersih pantai, dan $20 \%$ menyarakan untuk membuat perangkat sampah disetiap muara sungai. 


\section{Pelaksanaan Kegiatan}

Kegiatan bersih pantai kemudian dilakukan di Pantai Labuhan Haji pada tanggal 3 Februari 2019 tepat pukul 06.00 08.00 WITA. Lokasi yang dijadikan daerah utama kegiatan ini adalah dibagian utara Dermaga Labuhan Haji atau tepat di depan Hotel Meliwis. Sekitar 50 orang ikut ambil bagian dalam kegiatan ini, termasuk wisatawan yang sedang berada di lokasi tersebut. Para wisatwan secara sukarela mengikuti kegiatan ini setelah melihat publikasi kegiatan serta ajakan dari para peserta lainya. Peserta dibagi menjadi beberpa kelompok kecil yang berisikan 5 orang per kelompok. Setiap kelompok dilengkapi peralatan yang dibutuhkan termasuk kartu ICC untuk mencatat item pencemar.

Kartu ICC kemudian dikirimkan ke Ocean Conservancy, Washington DC, USA untuk di analisa dan dimasukkan ke dalam laporan tahunan. Berdasarkan analisa yang dilakukan oleh penulis, diperoleh total sebanyak 3933 item bahan pencemar dari lokasi kegiatan yang tebagi menjadi beberapa sumber pencemar seperti yang terlihat pada gambar 1. Bahan pencemar yang terdiri dari potongan plastik kecil paling mendominasi yaitu sebanyak 1623 item. Hal ini menunjukkan bahwa potongan plastik kecil ini merupakan bahan pencemar yang berasal dari bahan plastik utuh seperti bungkus permen, botol pastik atau benda yang terbuat dari plastik lainnya yang telah mengalami degradasi, karena keberadaannya yang telah

\section{Pasca Kegiatan}

Para peserta diberikan kuesioner pascakegiatan untuk mengetahui respon dan umpan balik dari peserta. Berdasarkan hasil wawancara dan kuesioner maka diperoleh data bahwa $100 \%$ peserta mendapatkan pengetahuan tentang bahan-bahan pencemar dan sumber pencemaran yang ada. Serta para peserta tahu arti dari pentingnya kebersihan pantai. Sebanyak 50\% menduga bahwa pencemaran berasal dari sungai yang bermuara ke pantai tersebut, bukan karena aktivitas dari para wisatawan, sementara 50\% lainnya menduga bahwa pencemaran berasal dari lama di pantai tersebut. Bahan pencemar yang berasal dari aktivitas rekreasi seperti bungkus permen atau snack, alat makan, botol plastik, kantong plastik, dan sedotan banyak sekali ditemukan. Hal ini juga menunjukkan tingginya tingkat pencemaran yang bersumber dari wisatawan di daerah tersebut, selain dari wisatawan bahan pencemar tersebut berasal dari sungai yang bermuara ke pantai tersebut. Bahkan melebihi pencemaran yang dilakukan oleh aktivitas pariwisata di pantai itu sendiri.

Sementara itu, puntung rokok juga ditemukan sebanyak 39 item. Hal ini terlihat dalam kurun 25 tahun terakhir bahwa aktivitas merokok dab bahan buangannya mencapai $32 \%$ jumlah item pencemar laut diseluruh dunia (Ocean Concervancy, 2011). Pampers atau pembalut dan kondom paling sedikit ditemukan yaitu masing-masing berjumlah 44 item dan 3 item. Bahan pencemar ini berasal dari sungai yang bermuara di pantai tersebut.

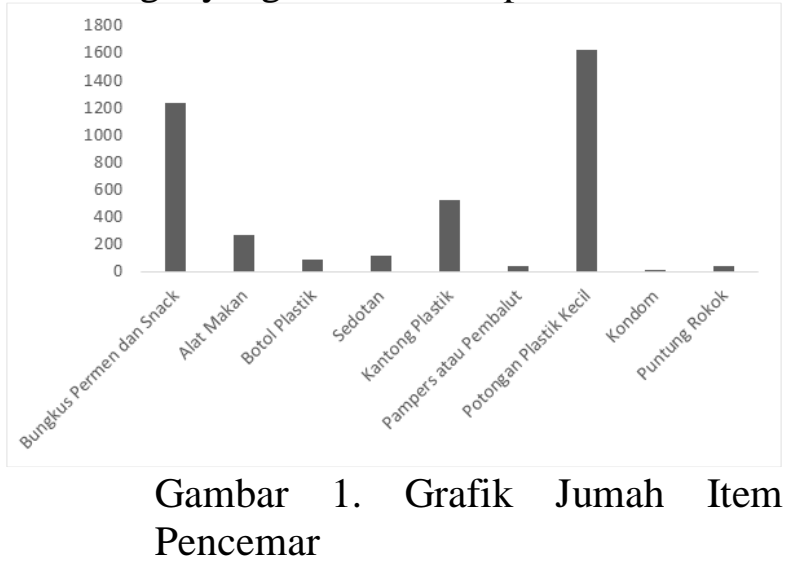

aktivitas wisata dan berasal dari warga dan warung-warung sekitar pantai.

Menurut para peserta, setelah melakukan kegiatan ICC ini, sebanyak $80 \%$ menyatakan bahwa kuantitas pencemaran yang ada telah berkurang secara kasat mata dan $20 \%$ menyatakan bahwa masih belum berkurang. Hal ini menunjukkan memang masih belum tuntas pelaksanaan ICC sehingga masih terlihat bahan-bahan pencemar di lokasi kegiatan walaupun dalam kuantitas yang kecil. Semua peserta menyatakan dukungannya untuk dilakukan kegiatan ICC secara rutin di lokasi tersebut. Para peserta juga menyarakan agar dilakukannya normalisasi sungai karena 
terlihat banyak sekali sampah yang menumpuk di bantaran sungai. Hal ini dikarenakan sampah yang ada disungai sebagai cikal bakal sampah yang akan menumpuk di pantai tersebut. Selain itu para peserta juga menyarankan agar disediakan tempat sampah di lokasi wisata tersebut. Hal ini terungkap karena minimnya sarana kebersihan seperti tempat sampah, sehingga tentunya akan menyulitkan wisatawan untuk membuang sampah.

\section{KESIMPULAN}

Kesimpulan yang dapat diambil dari kegiatan tersebut adalah konsep dan kegiatan ICC mampu meningkatkan pemahaman warga dan wisatawan terhadap pentingnya kebersihan pantai. Kegiatan tersebut dapat meningkatkan pengetahuan dan kepedulian warga terhadap beberapa jenis pencemar disekitar pantai. Perlu adanya keberlanjutan program serta penambahan fasilitas kebersihan di lokasi pantai tersebut.

\section{UCAPAN TERIMA KASIH}

Penulis mengucapkan terimakasih kepada Komunitas Plastik Bergerak yang telah membantu melaksanakan kegiatan ini sehingga berjalan dengan lancar. Ucapan terimaksih juga disampaikan kepada Fakultas Perikanan UGR, Green Generation Lombok Timur, dan semua yang telah terlibat dalam kegiatan tersebut.

\section{DAFTAR PUSTAKA}

Adger WN, Hughes TP, Folke C, Carpenter S R, Rockström J. 2005. Socialecological resilience to coastal disasters. Science, 309, 1036-1039.

Dahuri, R. 2002. Membangun Kembali Perekonomian Indonesia Melalui Sektor Perikanan dan Kelautan. LISPI: Jakarta.

Field CB, Behrenfeld MJ, Randerson JT, Falkowski P. 1998. Primary Production of the Biosphere: Integrating Terrestrial and Oceanic Components. Science, 281, 237-240.

Handaka, AA., I. Riyantini, M.Y. Awaluddin. 2007. Kepedulian Masyarakat
Terhadap pencemaran di wilayah pesisir Pameungpeuk Kabupaten Garut. Jurnal Akuatika. FPIK Unpad. Jambeck JR, Geyer R, Wilcox C, Siegler TR, Perryman M, Andrady A, Narayan R, Law K L. 2015. Plastic Waste Inputs from Land into The Ocean. Marine Pollution. Science. VOL 347 ISSUE 6223. American Association for the Advancement of Science (AAAS)

Ocean Concervancy. 1997. Tracking Trash 25 Years of Action for teh Ocean. Organisation Report. 43pp.

Ohkura, Y. and Kojima, A., 2007. International Coastal Cleanup Campaign Coordinated by JEAN in Japan Present state and future prospects. The 2nd NOWPAP Workshop on Marine Litter. 28-29 March.

Pauly D, Christensen V. 1995. Primary Production Required to Sustain Global Fisheries. Nature, 374, 255257.

Small C, Nicholls RJ. 2003. A Global Analysis of Human Settlement in Coastal Zones. Journal of Coastal Research, 19, 584-599.

Smith S, Marlic A. 2013. Estimates of marine debris accumulation on beaches are strongly affected by the temporal scale of sampling. PloS one. 8(12): e83694. 